\title{
INTEGRATED SHOPPING CENTRE AS A COMPONENT OF THE COMPACT CITY
}

\section{Marija Cvetković}

\section{A B S S T R A C}

In this paper we will present compact city planning and design concept, which compared to other concepts of the sustainable urban form, most fully incorporates all relevant topics and urban policies, such as increasing the density of development, ensuring a mix of uses, containing urban 'sprawl' and achieving social and economic diversity and vitality. We will examine integrated shopping centre as a component of the compact city, and establish its relationship with the concept of the compact city and its characteristics. The shopping centre concept in historical city core areas is not originally a sustainable concept. Instead, the concept of adaptive reuse of old industrial buildings located in the vicinity of city centre into retail functions is considered more sustainable and can be considered as a component of the compact city planning. The aim of this study is to examine the importance of integrated pedestrian environment for urban realm within the framework of the compact city concept. In order to determine the level of compatibility between the principles of sustainable urban form and the integrated shopping centre (ISC) principles of design, we will examine several case studies of shopping malls in the Czech Republic and Poland which are designed with the ISC principles in mind.

University of Belgrade - Faculty of Architecture

marija.cvetkovic@arh.bg.ac.rs

KEY WORDS

Ivan Simić

University of Belgrade - Faculty of Architecture

COMPACT CITY

ivan.simic@arh.bg.ac.rs

INTEGRATED SHOPPING CENTRE

SUSTAINABLE URBAN FORM

ADAPTIVE REUSE 


\section{INTRODUCTION}

In scientific research related to sustainable urban development, urban forms are treated as a significant environmental factor that affects energy consumption, ${ }^{1}$ pollution, ${ }^{2}$ ecology and biodiversity ${ }^{3}$ and climate change. ${ }^{4}$ The sustainable city form is a topic of different concepts and models of sustainable planning and design classified by Jusef Jabareen into four basic ones: neo-traditional development, urban containment, compact city, and eco-city. ${ }^{5}$

In this paper, we will present compact city planning and design concept (CCP), which compared to other concepts of sustainable urban forms, most completely incorporates all relevant topics and urban policies, such as increasing the density of development, ensuring a mix of uses, containing urban 'sprawl' and achieving social and economic diversity and vitality. ${ }^{6}$ The compact city characteristics include economic density (employment and population density), morphological density, which is specifically related to the built environment (e.g., compact urban land cover, street connectivity, high floor area ratios), and mixed use (e.g., co-location of residential, commercial and retail uses). ${ }^{7}$

As a component of the compact city, we will present the integrated shopping centre (ISC) and establish its relationship with the concept of the CCP and its characteristics. The shopping centre concept in historical city core areas is not a sustainable concept, but rather the concept of adaptive reuse of old industrial buildings located in the vicinity of city centre into retail functions is considered more sustainable and can be considered as a component of compact city planning. Shopping centre activity has simply transformed into an integrated part of the city itself. Integrating this concept requires a fine-grained grid development that engages the pedestrian circulation and offers interconnectivity of city functions, which allows the shopping centre and its surroundings to achieve mutual synergy.

The aim of this study is to examine the importance of integrated pedestrian environment for urban realm within the framework of the compact city concept. In this paper, shopping centres integrated in historical core of the city are considered as a positive example of modern consumer space as a component of the compact city.

Compact urban planning and design concept is widely accepted both in scientific research as a theoretical concept, and in urban planning and in the management of policies and strategies for sustainable development. Initially 
created in the United States by George Dantzig and Thomas L. Saaty as the mathematical model of optimal energy consumption, ${ }^{8}$ this concept was taken over by American urban planners, above all Jane Jacobs, in the era of planning cities opposed to development according to the principle of urban sprawl and car dependence. ${ }^{9}$ The compact city promotes short distances, high built-up densities and a combination of land use that should contribute to reducing energy consumption for traffic, but also other benefits such as creating neighbourhoods that are desirable to live in, preserving the vitality of the city centre, and so on. The CCP affects the policies and strategies for developing cities around the world. The European Commission's Green Paper "Towards a new culture for urban mobility" promotes a planning policy of "city of short distances". Urban policies that promote the principles of the compact city are highly represented in European countries. In the UK, initiatives such as an independent report by members of the Urban Task Force entitled "Towards an Urban Renaissance" has been published and "Planning Policy Guidance on Housing (PPG3)" adopted, aimed at the optimum utilisation of the existing city areas such as brownfield sites and increasing housing density. In the Netherlands, the "groeikernenbeleid" policy, and more recently, "Groene Hart" (Green Hart amid the Randstad) seeks to preserve agricultural and natural areas and to clearly delineate with the areas of cities.

Despite being widely accepted in scientific research and strongly advocated as the official policy of sustainable development in many regions and cities around the world, it is necessary to indicate critical attitudes towards the concept of the compact city. The most common criticism is related to the so-called intensification paradox that indicates that a building intensification policy that will increase population density will reduce per capita car use, but also increase the concentration of motor vehicles, having a negative impact on the local environment in those locations where it occurs. ${ }^{10}$ Other critics point out that a compact and densely built environment lacks free green areas as well as a large percentage of sealed impervious surfaces that can result in the emergence of the heat island effect. ${ }^{11}$ Like other theoretical concepts of sustainable built environment, the CCP lacks convincing empirical results, which will confirm the assumptions about the impact of urban forms on the environmental, social and social processes.

However, from the perspective of urban planning, which is the focus of this paper, the CCP as a theoretical and normative concept, is a research base that has given the most coherent system of aspects and criteria for sustainable urban forms. 
In order to determine the level of compatibility between the principles of sustainable urban form and the ISC principles of design, we will examine several case studies of shopping malls in the Czech Republic and Poland, which are designed in line with the ISC principles. We will adopt classification of the $\mathrm{CCP}$ criteria given by Jenks and Jones as the most relevant and comprehensive system of criteria for sustainable urban forms.

\section{ASPECTS AND CRITERIA FOR SUSTAINABLE URBAN FORMS ACCORDING TO JENKS AND JONES}

The most comprehensive scientific study of urban forms that relies on the CCP concept is given by British scholar Mike Jenks. He sets out some physical and non-physical characteristics of urban forms such as size, shape, density, land use, building typology, a city block matrix and the distribution of green spaces classified in five general and interdependent categories that form the shape of a city: density, type of dwelling/house, city matrix, land purpose, and traffic infrastructure. In his research, he starts from the assumption that the more compact, high-density and mixed-use urban forms are environmentally sound, efficient for transport, socially beneficial and economically viable. ${ }^{12}$

He also emphasizes the importance of the multicultural approach to examining the city's form, i.e. the importance of considering the spatial scale in any research of urban forms. These are levels of houses, streets, blocks, neighbourhoods, cities and regions. These analytical levels essentially affect how urban forms are measured, analysed and, consequently understood..$^{13}$

Pointing to the general consensus of attitudes about the aspects of a sustainable built environment, Jenks adopts the following four main aspects of the compact city: land use, energy conservation, recycling and reuse and communication and transport. ${ }^{14}$ Each of the aspects has criteria and attributes that describe them in more detail (Table 1).

In order to empirically test his assumptions, Jenks adopts these aspects and develops a system of criteria for the quantitative evaluation of the relationship between urban forms and the environmental, social and economic sustainability. In the study of five cities in the UK and their distinctive urban patterns, Jenks and Jones for the selection of polygons select, among other things, typology of objects and three spatial scales, including the city, the case study area (or neighbourhood), sub-areas, the street and individual dwellings. 


\begin{tabular}{|c|c|c|c|}
\hline $\begin{array}{l}\text { LAND USE AND } \\
\text { BUILT FORM }\end{array}$ & ENERGY EFFICIENCY & $\begin{array}{l}\text { RECYCLING AND } \\
\text { RE-USE }\end{array}$ & $\begin{array}{l}\text { COMMUNICATION AND } \\
\text { TRANSPORT }\end{array}$ \\
\hline $\begin{array}{l}\text { Intensive use of urban } \\
\text { land } \\
\text { Networks of green } \\
\text { corridors } \\
\text { Community buildings, } \\
\text { self-managed } \\
\text { Mixture of land uses at } \\
\text { relatively high density } \\
\text { Affordable homes } \\
\text { Local identity } \\
\text { Sustainable building } \\
\text { materials } \\
\text { Flexible design and } \\
\text { good space standards } \\
\text { Improved noise } \\
\text { insulation }\end{array}$ & $\begin{array}{l}\text { Combined heat and } \\
\text { power (CHP) - local } \\
\text { power generation } \\
\text { Micro power } \\
\text { generation } \\
\text { Renewable energy } \\
\text { Reduced energy } \\
\text { consumption and } \\
\text { embodied energy } \\
\text { High levels of } \\
\text { insulation } \\
\text { Intelligent lighting and } \\
\text { integrated security, } \\
\text { heating, and IT systems } \\
\text { 'A' rated white goods } \\
\text { Eco-rating e.g. } \\
\text { BREEAM 'excellent' }\end{array}$ & $\begin{array}{l}\text { 'Grey' water systems } \\
\text { Recycle water for } \\
\text { gardening and car } \\
\text { washing } \\
\text { Reuse water and } \\
\text { filter, to be directed to } \\
\text { ecology parks or green } \\
\text { spaces } \\
\text { Waste recycling, and } \\
\text { use for production of } \\
\text { biogas } \\
\text { Reduced domestic and } \\
\text { construction waste } \\
\text { Carbon-neutral lifestyle }\end{array}$ & $\begin{array}{l}\text { Light transit routes, } \\
\text { eco-friendly buses and } \\
\text { bikeways } \\
\text { Car clubs and cycle } \\
\text { facilities } \\
\text { Pedestrian-friendly } \\
\text { infrastructure } \\
\text { Restricted car parking } \\
\text { Environmental advice } \\
\text { - bus/transit times, } \\
\text { energy and water } \\
\text { monitoring } \\
\text { IT enabled }\end{array}$ \\
\hline
\end{tabular}

Table 1. Aspects of a sustainable built environment (Jenks, 2010, p. 3) 
Although critics of his research state that Jenks' attributes of urban forms do not adequately differentiate urbo-morphological, design, and spatial parameters of the form, ${ }^{15}$ they still remain one of the most complete contributions to the theory of sustainable urban forms since they are based on empirical and quantitative measurements for which he developed a system of aspects and criteria.

\section{INTEGRATED SHOPPING CENTRE - ISC}

The aim of this study is to examine the importance of integrated pedestrian environment for urban realm within the framework of the compact city criteria. In this paper, shopping centres integrated in historical core of the city are considered as a positive example of modern consumer space as a component of the compact city. On the one hand, modern activities are combined in this centre, with shopping activities organised in a practical and pleasant environment. On the other hand, they are becoming an integral part of historical city environment, encouraging the revival and renewal of this sensitive part of the urban core. There are positive aspects of indoor pedestrian spaces such as security, weather control, concentration and variety of content, but indubitably, there are negative aspects such as social stratification, reducing street activity, the decline in streetscapes, etc. Positive aspects of indoor pedestrian places can be matched with the positive aspects of urban pedestrian environment. The question which should be examined is how it relates to the existing city. ${ }^{16}$ As Nadine Beddington ${ }^{17}$ states, a shopping mall in the city centre needs to be integrated into existing environment by means of architecture, but synergy between the old and the new, the traditional and the contemporary in the existing pedestrian zone is essential to successful integration of the new shopping centre. Therefore, preserving and developing the existing pedestrian links and intensification of street life are the primary concepts while integrating interior pedestrian places into urban realm.

Since the 1980s, the focus of urban planners in Western Europe and developed countries has shifted from construction of new shopping malls to the regeneration and revitalisation of the open public spaces. However, there is a surge in the construction of new shopping malls in Serbia and other Eastern European countries. The recent economic decline in Serbia has extinguished the glow of consumerism from a few decades ago. Only the largest and strongest shopping malls have survived, while small local malls created inside former department stores are shutting down. 


\section{ADAPTIVE REUSE OF INDUSTRIAL BUILDINGS TO RETAIL AS A PRINCIPLE FOR SUSTAINABLE URBAN FORM}

The implementation of the sustainability principle in contemporary planning practice has resulted in a trend towards brownfield regeneration: "the redevelopment of land or premises which has previously been used or developed and is not currently fully in use." ${ }^{\prime 18}$

The process of adaptive reuse is closely related to the preservation and revitalisation of historical centres and its heritage buildings. Adaptive reuse is also a valuable instrument for sustainable development, it becomes a discipline of interest not only in a European context, but also in a global perspective. As demolition and construction are by far the largest producers of waste, it is clear that reducing waste is vital for creating environmentally friendly buildings and interiors. Reusing and adapting existing buildings with outdated functions is considered to be one of the principles of sustainable planning (of urban forms) as the amount of resources needed for reuse is far less than those needed for newly built structures, as of reduced domestic and construction waste and use of sustainable building materials. Furthermore, when the existing building has historical or architectural significance, it provides a connection to our cultural and collective memory ${ }^{19}$ and it preserves local identity. As adaptive reuse is considered highly sustainable - environmentally and socially - the first step towards sustainable retail design is reusing an abandoned historic building. ${ }^{20}$

Nowadays, the integration of shopping malls into urban fabric is becoming increasingly important. Sustainable design for shopping malls is a rising trend, and there are shopping malls that are designed on the principles of concept of the compact city by integrating a shopping centre into pedestrian zone in the urban city core with synergy between the old and the new, the traditional and the contemporary. One of the leading ways for integrating retail is an adaptive reuse of former industrial buildings. Carefully located and well-integrated shopping centres can contribute to the promotion and regeneration of historic urban and architectural heritage, where positioning a shopping centre in the pedestrian zone or in the proximity to the historic city has contributed to maintaining activities and people, thus to the preservation of city values. By observing shopping centres, we can notice that there is a trend of designing them on brownfield locations as well as imbedding and integrating them into a renewed pedestrian-friendly infrastructure in order to reduce the impact of traffic as well as to expand the pedestrian zone. 
With construction of shopping centres in the already built and formed urban fabric of the environment, it is transformed in the physical, functional and social sense. The space of the modern city is transformed by creating new forms and transforming the existing structure through the positioning of retail space as stated by Dawson, Goss and Howard. ${ }^{21}$ The location of the shopping centre in the built environment has an undeniable influence on the economic, ecological and social aspect of the area. Commission for Architecture and the Built Environment (CABE) research maintains that architecture affects everything, every hour of the day, and good design ${ }^{22}$ is very important in the appearance and ambience of the urban environment. It is raising the awareness of the community and influences the behaviour and feelings of the visitor. Good design improves the quality of life for everyone, in short.

Shopping centres provide an isolated, climate-controlled pseudo-public space, especially in suburbs, where they are beginning to function as cities within neglected surroundings. This type of a shopping centre creates competition within shopping spaces of the city: a traditional pedestrian mall in the historic city and the shopping centre. Nevertheless, shopping centres can be built inside the city urban core and participate in pedestrian life, creating synergy, integrating with pedestrian malls $\mathrm{s}^{23}$ or squares, which can help to create a more integrated pedestrian environment by means of interior and exterior places. By definition, inner-city shopping centres are more integrated into the urban fabric. For example, the hybrid centres combine open spaces with enclosed interior spaces. Shopping areas are being reinvented into open public spaces, within tempered, open and covered streets, fully integrated with urban fabric. ${ }^{24}$ According to Dawson, ${ }^{25}$ the location and accessibility are the most important determinants for the success of a shopping centre. Successful pedestrian-based shopping areas tend to be located in the locally most integrated areas. This area tends to be on streets with high local integration values and a high degree of connectivity with their immediate vicinity. ${ }^{26}$

Shopping centres can be integrated and designed in the city's historical centre and enable an integrated pedestrian environment through the creation of synergy between the interior and the exterior of that space, which is not only provided by a shopping area. With a good design of their spatial and functional solutions, they satisfy and support the vitality of open public spaces of the historical city core in which they are located. A shopping centre that is better integrated into the urban environment has a more positive impact on the quality of the urban environment. The assumption is that, as new leisure facilities and new venues for gathering shopping centres, they contribute to increasing the quality of life 
in the urban area, if they are adequately designed and physically, functionally and socially integrated into the urban structure. Shopping malls that better integrate traditional aspects of public space make a more positive contribution to the urban fabric in which they are located by providing the mix of different users, the option of extending stay, contributing to the continuity of space, entering a new identity or redefining the old one. Well-integrated shopping centres allow for better functional-physical and socio-cultural integration into a particular urban environment. They contribute to improving the characteristics of the physical environment, functionality, social and symbolism of the urban area, and also improve the quality of life of inhabitants of the immediate urban environment. Depending on the level of integration of the shopping centre with the surrounding functions and form, it depends how much it contributes to improving the characteristics of the physical environment, functionality, social and symbolic character of a particular urban area.

The particular relationship between historic architecture - heritage - and retail design has only received limited attention by scholars to date. Kirby and Kent $^{27}$ recognise the reuse of historic buildings as a means for place branding. Warnaby ${ }^{28}$ investigates the potential for historical architecture to contribute to the experience enjoyed by the retail users in towns and cities. Onay ${ }^{29}$ studied a number of case studies of antique buildings in Florence, Italy of which the ground floor is transformed into a shop. Brown and Maclaren ${ }^{30}$ studied consumer experience in the case study of Powerscourt Townhouse Centre, a shopping centre located in a historic building in the heart of Dublin, Ireland. Therefore, we recognise two different levels of how heritage can make a possible contribution towards retail branding: firstly, at the level of an individual store located in a historic building; and secondly, at an urban level, regenerating larger historical sites or districts into retail areas. However, research on the integrated shopping centre concept as a component of compact city is yet to be conducted. Therefore, the primary focus of this paper is the exploration of integrated shopping centres as a component of compact city for sustainable urban forms. It presents a preliminary study of this phenomenon in four shopping centres across Europe.

\section{INTEGRATED SHOPPING CENTRE EXAMPLES - ADAPTIVE REUSE VIA THE CCP CRITERIA}

In order to understand the strategy of shopping mall development better, why and how today's integrated shopping malls have evolved, it is necessary to identify the physical elements within its structure and analyse the historical background. There are few examples of successful integration of shopping 
malls in the cities of Serbia and Eastern Europe. Here, placing a shopping centre in the pedestrian zone or in the vicinity of the historic city has contributed to maintaining activities and people, thus to the preservation of city values. This type of the shopping centre can be embedded and built in the historical centre with galleries, parks, and patios, which enables integrated pedestrian environment. Apart from commercial space, they can create a synergy between the interior and the exterior. In this paper, we will focus on two types of integrated shopping centres, mostly focusing on relation to the city centre, and architectural aspects of design and their embodiment: shopping centres built by using urban recycling of existing industrial facilities, in the vicinity of pedestrian mall and historical urban centre of the city. By examining the use of urban recycling of existing industrial facilities, we can explore how adaptive reuse of old industrial buildings and complexes in historic urban core can be used during this integration.

Stary Browar, Poznan, Poland

(Bui1t: 1844-80; Redeveloped: 2003-07)

Exploring the aspects of land use and built form in Stary Browar (Figure 1) complex $\left(130,000 \mathrm{~m}^{2}\right)$, which consists of a renovated old brewery and new buildings that are built as part of an old industrial complex, thus preserving local identity and using new sustainable building materials; we can note that it benefits from flexible design and good space standards.

Buildings were significantly destroyed in the post-war years continued to be used as a beer factory until 1970. After the closure of the factory in 2002, part of the complex was used for theatrical performances. The ruined industrial complex was renovated for reuse in 2003. The complex is designed for cultural, business and shopping purposes: the atrium (east wing), an art gallery and a shopping centre (west wing). Operas, exhibitions, festivals, film screenings, dance performances, etc., are often held here. Old brewery today bears a strong architectural spirit. It is achieved through the combination of red brick facade and modern elements of glass and steel, which accentuates the identity of the area as a former industrial complex. The appearance and style of the complex do not resemble a traditional shopping centre. Its design respects the old buildings, which are easily recognisable and visually prominent. In addition, the "spirit" of the historic industrial complex is retained by the use of existing materials, with reduced domestic and construction waste (using the original bricks from the original industrial complex) in combination with the modern elements of glass and steel, embedded into the structure so it maintains the identity of the old industrial complex. 


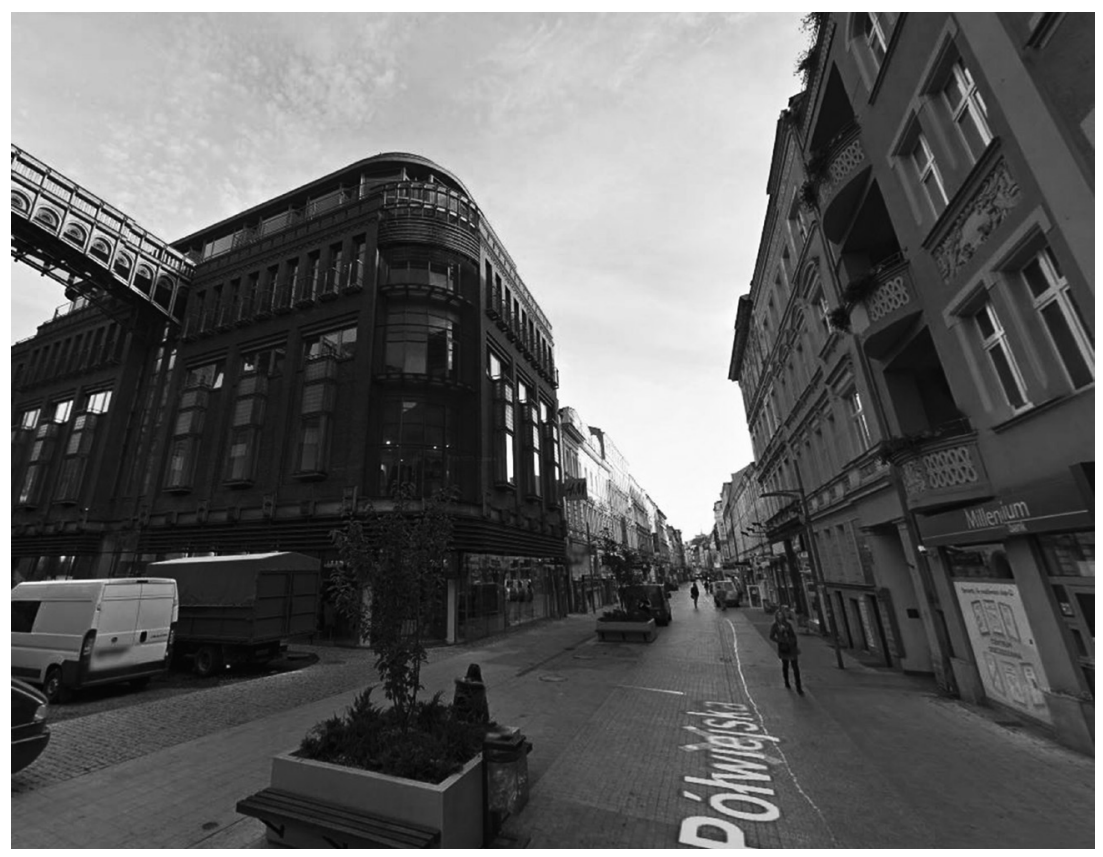

Fig. 1. Stary Browar

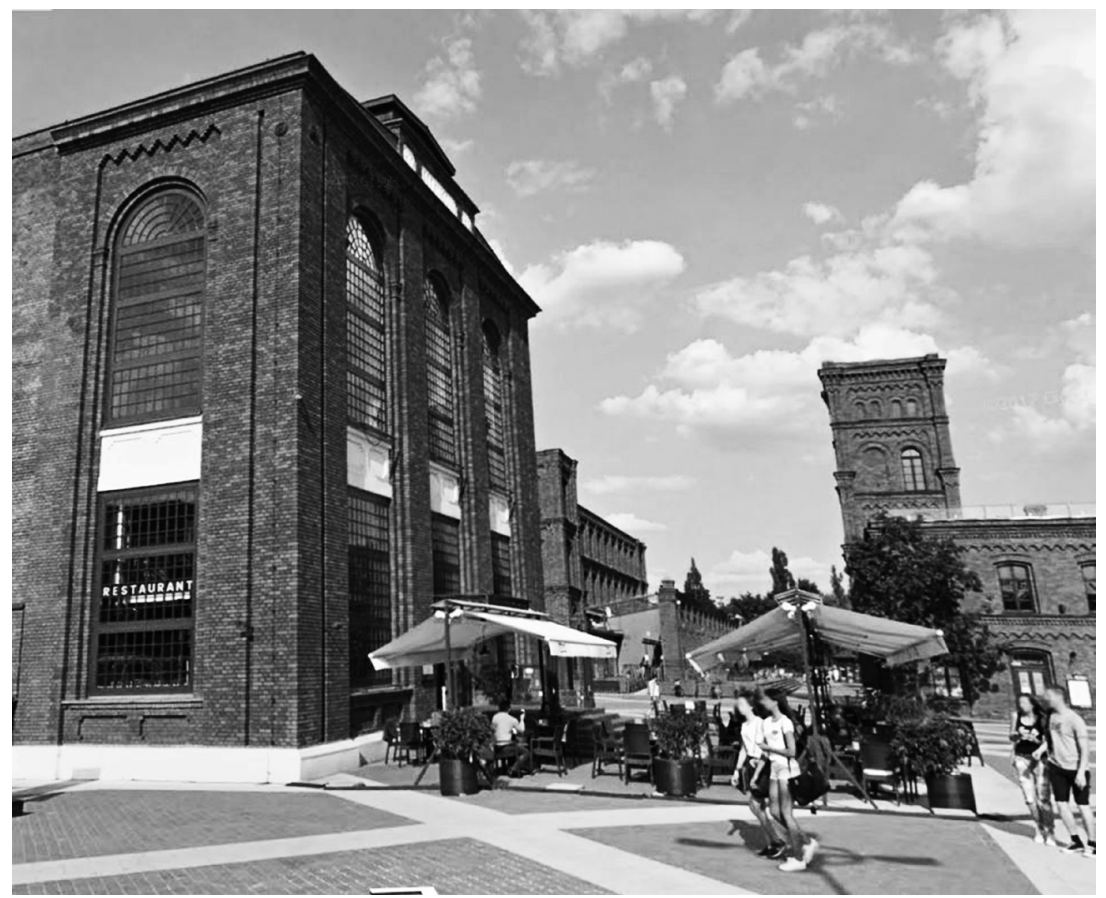

Fig. 2. Manufaktura 
With respect to communication, it can be noted that this complex is easily accessible and it is a pedestrian-friendly infrastructure given it is located tangential to the main pedestrian street of historical core - Półwiejska Street (700 $\mathrm{m}$ in length). This location supplements and enhances the existing content of this street, which has become one of the most popular places for socialising in the city, along with a common circular central courtyard (Rundbogen).

Manufaktura, Łódź, Poland

(Bui1t: 1871-90; Redeveloped: 2001-07)

The Manufaktura (Figure 2) centre is multifunctional complex which comprises an art centre, a shopping mall, and a leisure complex. In 2006, one of the largest former factories in the city was transformed into a mix of shopping, hospitality, leisure and cultural functions. This project includes the restoration of existing buildings reducing domestic and construction waste - mainly applying the concept of façadism - as well as new structures using sustainable building materials. As there has been a lack of well-organised public space in the centre of Łódź, major attention was given to creating a central square. In the years following the opening of the complex, other initiatives of adaptive reuse of industrial sites by private investors have been realised in the city centre. Today, Manufaktura strongly contributes to upgrading the image of Łódź both within and outside Poland by preserving local identity.

This complex $\left(270,000 \mathrm{~m}^{2}\right)$ is a pedestrian-friendly infrastructure and it is situated in the proximity $(200 \mathrm{~m})$ of historical city core and the main pedestrian street - Piotrkowska Street ( $4.2 \mathrm{~km}$ in length), in the vicinity of a city park. This street was customised to vehicles from its early beginnings. During the Industrial Revolution-era, it became the centre for retail and entertainment the whole life of industrial agglomeration was concentrated there. The street lost its significance after World War II. City authorities tried to revitalise it during the 1990s. Nevertheless, the importance of the central part of the Łódź faded during this decade due to the opening of several shopping centres on the city's outskirts. Only after the old textile factory in the Manufaktura centre was renovated, the redevelopment of the historic core of Łódź and its main symbol, Piotrkowska Street, was obtained. Hence, new shopping centre has supplemented and expanded the existing functions of open public space by intensive use of urban land. 


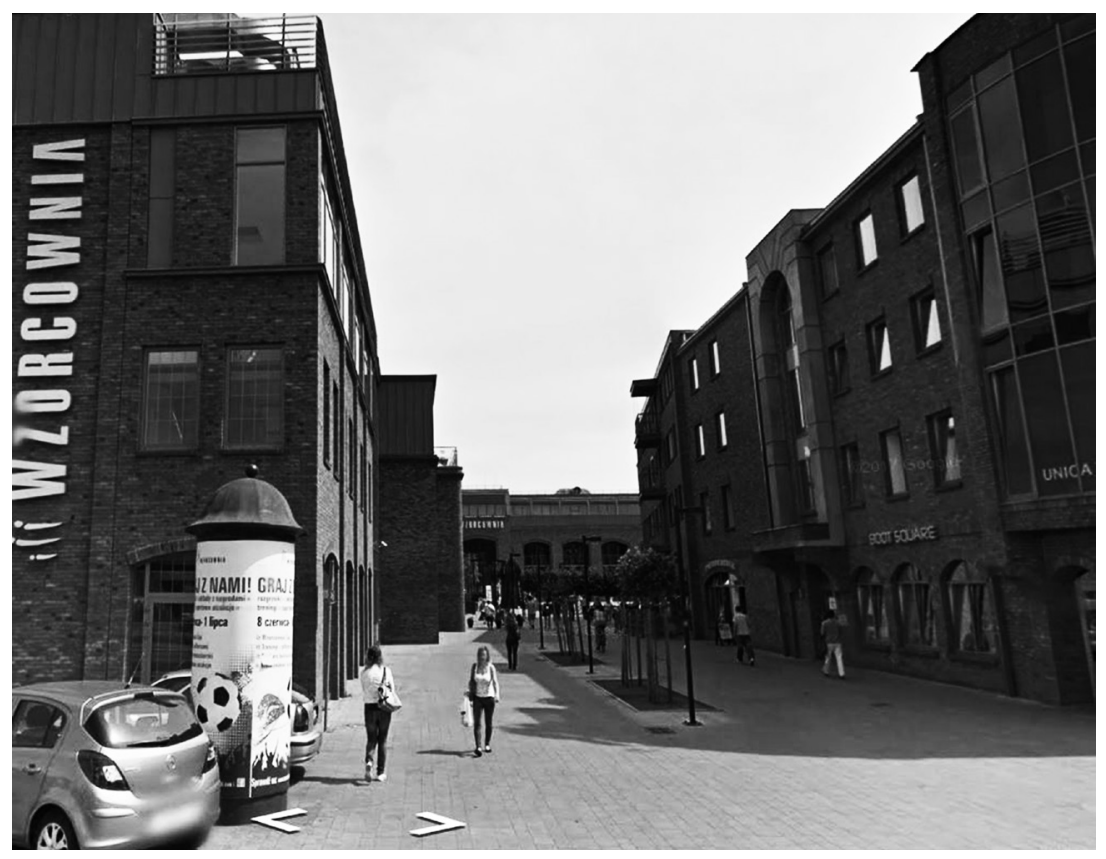

Fig. 3. Wzorcownia Włocławek

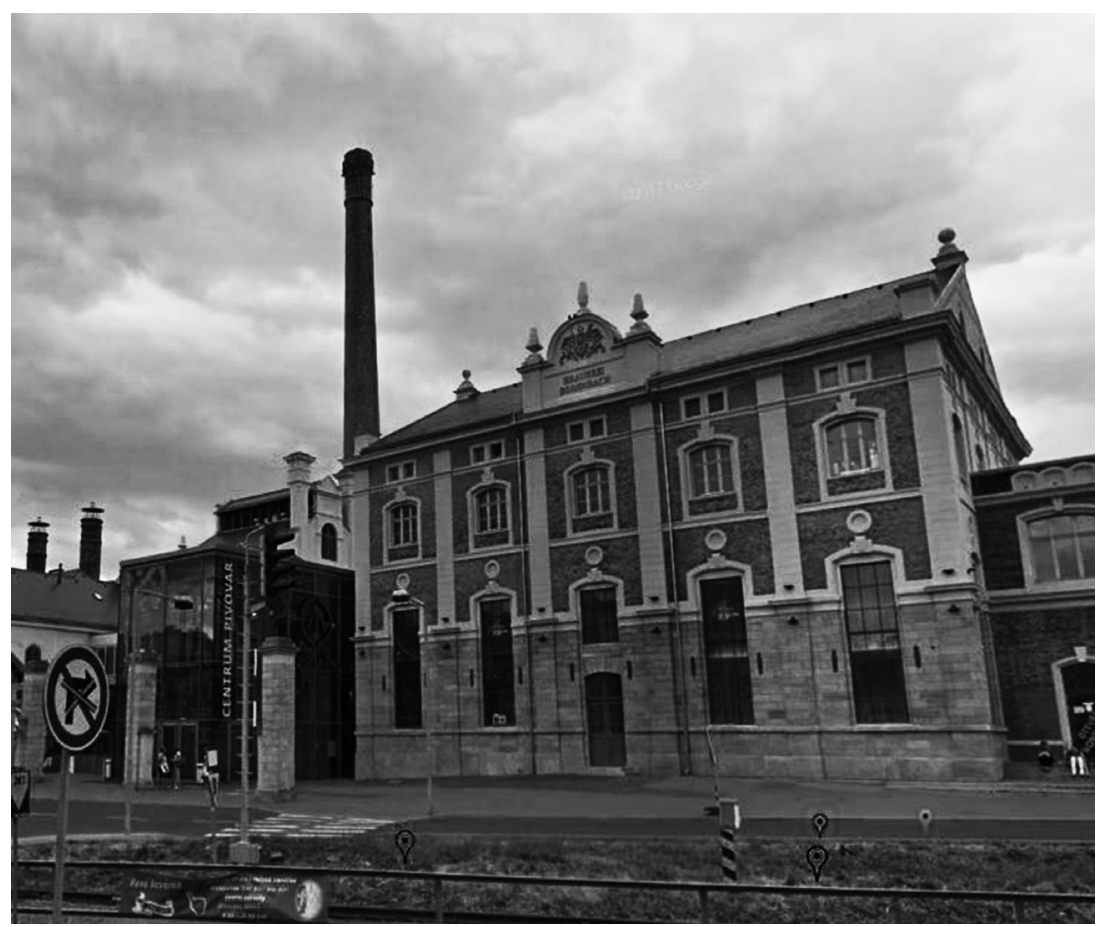

Fig. 4. Pivovar Děčín 
The revitalisation was aimed at preserving the ancient atmosphere of this place and the Manufaktura complex is thereby dominated by genuine industrial architecture, with unplastered red brick buildings. The complex's trademark is the old, five-storey spinning mill on Ogrodowa Street, built in 1877-1878. A four-star hotel Andel's opened in 2009. The other buildings in the complex were reconstructed in the same authentic manner. The exception to this approach is the main shopping hall, which is a new structure, mainly made from glass and steel. But it is lower than the surrounding brick buildings, and therefore, it cannot be seen from the outside, maintaining the authenticity of the historical spirit of the city. Despite the latest technological solutions implemented in the renovation project, the original historical structure of the place has been preserved. This project is a clear example of the commercial reuse of heritage that boosted local economy and development by using a flexible design and good space standards. Yet, historic buildings often perform poorly in terms of energy efficiency and, as such, are not invariably beneficial in ecological terms. This causes particular technical challenges to architects, interior architects and engineers dealing with adaptive reuse, which has led to the development of extended theories and studies on technical aspects of adaptive reuse.

Wzorcownia Włocławek, Poland

(Bui1t: 1873; Redeveloped: 2009)

Wzorcownia (Figure 3) is the first and only multifunctional urban project in Włocławek located in the centre of the city. It is pedestrian-friendly infrastructure located in the very centre of the city. The Centre $\left(80,000 \mathrm{~m}^{2}\right)$ was established on the revitalised area of the former faience factory that once produced the famous "włocławki". Wzorcownia is located between the Kosciuszki, Kilinskiego, Pulaskiego and Bauer streets, at the main communication axis, by the E75 / national road no. 1. A railway and bus station is located in close proximity to Wzorcownia.

The transformation of the city's brewery, which had been unused and dilapidated for years, created a new multifunctional centre and preserved local identity and, along the way, reduced construction waste. It is an example of a commercial concept consisting of sophisticated architecture, good commercial and entertainment offer, use of sustainable building materials, flexible design and a city centre location. Wzorcownia is an example of a passive building that uses renewable energy and the latest energy-saving and environmentally friendly technologies. Mobile escalators installed in the centre are the latest generation devices, powered by inverters, which save up to $60 \%$ of electricity compared 
to traditional stairs. The use of revolving doors also contributes to the thermal energy efficiency in comparison to the automatic sliding doors commonly used in shopping centres. The green roof greatly improves the thermal insulation of the building by reducing energy consumption and embodying energy. The heating, ventilation and air conditioning, as well as lighting, are BMS system control - Building Management Systems.

\section{Pivovar Děčín, the Chech Republic}

(Bui1t: XVII; Redeveloped: 2014)

The building of the commercial and socio-cultural centre of Pivovar Děčín (the Decin Brewery, 32,500 $\mathrm{m}^{2}$ ) (Figure 4) is located in the former brewery of Decin Podmokly, the Czech Republic. The core of the building consists of a two-story shopping mall with more than 60 retail units, covering a leasable area of 17,500 square meters. The unique multifunctional centre was created by a sensitive combination of the original historical parts of the brewery buildings, the first of which date back to the turn of the seventeenth and eighteenth centuries, with new modern elements of architecture.

Reconstruction of the Děčín brewery is unique because the historical part of the shopping centre was connected with the newly built part of the mall. The main idea of the whole concept builds on using and preserving the original buildings and reducing construction waste in a harmonious balance with the construction of the new retail spaces and technical facilities built with sustainable building materials. These buildings with various unique spaces and structures have been renovated and reused for both classical and specific business units. The configuration is based on joining two previous inner courtyards situated at the centre of the historical part of brewery. The modulation of the shopping mall is subordinated in favour of the optical and physical connection between the interior with the exuberant front courtyard facades and the exterior new system, connecting the city centre with the multifunctional complex.

Much of the site is supplied with electricity from solar collectors. Although some buildings are really old, they should belong to the category of the least energy intensive and therefore environmentally-friendly facilities. This complex uses renewable energy and also makes use of underground water supplies from the local wells. 


\section{CONCLUSION}

Some authors defend that modernity or better yet post-modernity should be given an opportunity as a city is made of several periods in time, ${ }^{31}$ all of which, should be entitled to their own place within a balanced and respectful atmosphere and a mix of land-uses or reuses, especially in the old fabric of a city. The process of urban recycling has revitalised not only the space, which has been directly renovated, but also the wider area of surrounding historical urban core, recovering their traditional identity of the central point in city. Although the given cases present just one of many possible approaches to simultaneously reusing and renewing abandoned industrial spaces and nearby historical urban core, they were implemented in the similar post-socialist environment with many "transitional" elements of uncertainty and fast changes. The aim of the paper is to encourage consideration that shopping centres are not in conflict with the urban core by 'definition', and to present through the best practice that carefully located and well-integrated shopping centres can contribute to the promotion and regeneration of historic urban and architectural heritage, where locating shopping centre in the pedestrian zone or their proximity of the historic city contributed to maintaining activities and people, thus to the preservation of city values.

By examining the use of urban recycling of the existing industrial facilities and the importance of integrated pedestrian environment for urban realm within the framework of the compact city concept on several case studies of shopping malls in the Czech Republic and Poland we have established that most of them are designed in line with the compact city principles. After examining the aspect of land use and built form it can be concluded that criteria of intensive use of urban land, local identity and criteria of sustainable building materials is matched in all case studies. Energy efficiency can be seen through its criteria of high-level insulation, renewable energy consumption and embodied energy as well as intelligent lighting and integrated security, heating, and IT systems in almost all newly built parts of this integrated shopping centres. Aspect of recycling and re-use can be seen in all case studies by the use of criteria of reduced domestic and construction waste because of adaptive reuse of old industrial buildings and complexes in historical urban core were used during this integration. As for aspect of communication and transport, this complex satisfies the criteria of pedestrian-friendly infrastructure because they are located in the vicinity of the city centre and designed as walkable spaces, with its own streets and squares. Integrated shopping centres can be considered as a component of compact city planning because they meet the great majority of compact city criteria. 

environment: impacts, adaptation and mitigation" (43007) financed by the Ministry of Education and Science of the Republic of Serbia within the framework of integrated and interdisciplinary research for the period 2011-2019.

$1 \quad$ Leslie Martin and Lionel March (eds.), Urban Space and Structures. (UK: Cambridge University Press, 1972); Carlo Ratti, Dana Raydan, and Koen Steemers. "Building form and environmental performance: archetypes, analysis and an arid climate," Energy and Buildings. No. 35 (2003): 4959; Perry PJ Yang, "Energy Resilient Urban Form: A Design Perspective," The 7th International Conference on Applied Energy - ICAE2015. Abu Dhabi, 2015.

Jason Song, Allan Webb, Brian Parmenter, Douglas Allen. and Ellen Mcdonald-Buller, "The Impacts of Urbanization on Emissions and Air Quality: Comparison of Four Visions of Austin, Texas," Environmental Science, Technology. No. 19(2008):294-300; Mirijam Schindler and Geoffrey Caruso, "Urban Compactness and the Trade-off Between Air Pollution Emission and Exposure: lessons from a Spatially Explicit Theoretical Model," Computer Environment and Urbanization, Vol. 45 (2014): 13-23.

Steve Hankey, Greg Lindsey, and Julian D. Marshall, "Population-level exposure to particulate air pollution during active travel: planning for low-exposure, health-promoting cities," Environmental Health Perspectives. Vol. 4 (2016): 527-34. 
Marina Alberti, "Urban Form and Ecosystem Dynamics," in Achieving Sustainable Urban Form (London: E\&F Spon, 2000), 54-63.; Nan Ellin, "Integral Urbanism: A Context for Urban Design," in Resilience in Ecology and Urban Design: Linking Theory and Practice for Sustainable Cities, edited by Steward Pickett, M.L. Cadenasso, and Brian McGrath (New York: Springer, 2013), 63-78; Steward Pickett, M. L. Cadenasso and Brian McGrath, Resilience in Ecology and Urban Design Linking Theory and Practice for Sustainable Cities (London: Springer, 2013).

Nicole Gurran and Elisabeth Hamin, "Urban form and the climate change, Balancing adaptation and mitigation in the U.S. and Australia," Habitat International (2009): 33; Paul Downton, Ecopolis, Architecture and cities for a changing climate (Dordrecht: Springer, 2009); Jeffrey Raven, "Cooling the Public Realm: Climate Resilient Urban Design," in Resilient Cities: Cities and Adaptation to Climate Change, edited by Konrad Otto-Zimmermann (Heidelberg: Springer, 2011), 451-463.

Yosef R. Jabareen, "Sustainable Urban Forms - Their Typologies, Models, and Concepts," Journal of Planning Education and Research 26 (2006).

Mike Jenks, Elizabeth Burton and Katie Williams. The Compact City: A Sustainable Urban Form? (London: E \& FN Spon, 1996); Mike Jenks and Nicola Dempsey, Future Forms and Design for Sustainable Cities (Oxford: Architectural Press, 2005).

Gabriel M. Ahfeldt and Pietrostefani Elisabetta, The compact city in empirical research: A quantitative literature review. SERC Discussion Papers (SERCDP0215: Spatial Economics Research Centre, London School of Economics and Political Science, London, UK, 2017).

George B. Dantzig and Thomas L. Saaty, Compact City: Plan for a Liveable Urban Environment (San Francisco: W. H. Freeman, 1973).

Jane Jacobs, The Death and Life of Great American Cities: The Failure of Town Planning (New York: Random House, 1961); Peter Newman and Jeffrey Kenworthy, Cities and Automobile Dependence, An International Sourcebook (Gower: Aldershot. 1989); Susan Handy, "Methodologies for Exploring the Link Between Urban Form and Travel Behavior," Series: Transportation Research, Transport and Environment, D 2 (2), (1996): 151-165.

Steve Melia, Graham Parkhurst and Hugh Barton, "The paradox of intensification," Transport Policy 18, Issue 1, (2011).

Jane Bicknell, David Dodman and David Satterthwaite, Adapting Cities to Climate Change (London: Earthscan, 2009); Nicole Gurran and Elisabeth Hamin, "Urban form and the climate change, Balancing adaptation and mitigation in the U.S. and Australia," Habitat International (2009): 33.

Mike Jenks and Colin Jones, Dimensions of Sustainable City, Vol. 2. (London: Springer, 2010).

Mike Jenks, Elizabeth Burton and Katie Williams, The Compact City: A Sustainable Urban Form? (London: E \& FN Spon, 1996); Mike Jenks and Nicola Dempsey, Future Forms and Design for Sustainable Cities (Oxford: Architectural Press. 2005).

Mike Jenks and Colin Jones, Dimensions of Sustainable City, Vol. 2. (London: Springer, 2010).

Mattias Karrholm, "Setting the Scale of Sustainable Urban Form - scale-related problems discussed in the context of a Swedish urban landscape," Conference Architectural Inquiries (Göteborg, 2008).

Michael J. Bednar, Interior Pedestrian Places (New York: Watson-Guptill. Publications, 1986).

Nadine Beddington, Shopping Centres: Retail Development, Design and Management (London: Butterworth Architecture, 1991), 11.

Ana Perić, "The Role of Local Governance in the Process of Brownfield Regeneration: European Planning Practice," in Serbian Architectural Journal, Volume 7, No. 3, 2015, 264. Available at: http://saj.rs/wp-content/uploads/2017/03/SAJ-2015-03-A-Peric.pdf.

Graeme Brooker and Sally Stone, Re-reading: Interior Architecture and the Design Principles of Remodelling Existing Buildings (London: RIBA Publishing, 2004). 
Bie Plevoets and Koenraad Van Cleempoel, "Heritage, Adaptive Reuse and Regeneration in Retail Design," in Retail-Design: Theoretical Perspectives, eds. Ann Petermans, Anthony Kent, (London: Routledge, 2016).

John A. Dawson, Shopping centre development (London: Longman, 1983).

Jon. Goss, "Modernity and postmodernity in the retail built environment," in Ways of seeing the world, ed. F. Gayle and K. Anderson (London: Unwin Hyman, 1992); John Goss, "The "Magic of the Mall": An Analysis of Form, Function, and Meaning in the Contemporary Retail Built Environment," Annals of the Association of American Geographers 83, No. 1 (Mar., 1993): 18-47; Gillette Jr. Howard, "The Evolution of the Planned Shopping Center in Suburb and City," Journal of the American Planning Association 51 (2007): 4.

A good design is a design that suits its purpose, which is sustainable, efficient, coherent, flexible, appropriate to the context, has a good appearance and a clear expression. CABE, 2006.

Pedestrian malls as urban spaces have always been the major components of the city and play crucial roles in defining the characteristics of urban places. They create the city form and develop the connection between the exterior and interior spaces.

Peter Coleman, Shopping Environments: Evolution, Planning and Design. (Oxford: Architectural Press, 2007).

John A. Dawson, Shopping centre development. (London: Longman, 1983).

Akkelies Van Nes, “A configurative approach to understand pedestrian based and car-based shopping centres: Configurative studies on Oslo and Eindhoven," in Proceedings of The Fourth International Space Syntax Symposium (London, 2003), 78.

Audrie E. Kirby and Anthonie M. Kent, "Architecture as brand: store design and brand identity," Journal of Product \& Brand Management, no. 19 Issue: 6 (2010): 432-439.

Gery Warnaby, “Towards a service-dominant place marketing logic," Marketing Theory 9, No. 4 (2009): 403-423.

Saglar Onay, N, "Commercial use of Antique interiors: dialectics of the contemporary and the conservative." International Journal of Academic Research, 5(4), (2013): 161-168.

Pauline Maclaran and Stephen Brown, "The Center Cannot Hold: Consuming the Utopian Marketplace," Journal of Consumer Research, 32(2) (2005).

Jose. A. Rio Fernandes, "Sustainable urbanism: reducing, recycling, and reusing in a larger and more complex urban space," in Urban changes in different scales: systems and structures, edited by Lois González and Ruben Camilio (Universidad de Santiago de Compostela, 2006). 
Ahfeldt, Gabriel M. and Pietrostefani, Elisabetta. The compact city in empirical research: A quantitative literature review. SERC Discussion Papers (SERCDP0215). London: Spatial Economics Research Centre, London School of Economics and Political Science, 2017.

Alberti, Marina. "Urban Form and Ecosystem Dynamics.” In Achieving Sustainable Urban Form 54-63. London: E\&F Spon, 2000.

Beddington, Nadine. Shopping Centres: Retail Development, Design and Management. London: Butterworth Architecture, 1991.

Bednar, Michael J. Interior Pedestrian Places. New York: Watson-Guptill. Publications, 1986.

Bicknell, Jane, David Dodman, and David Satterthwaite. Adapting Cities to Climate Change. London: Earthscan, 2009.

Brooker, Graeme and Sally Stone. Re-reading: Interior Architecture and the Design Principles of Remodelling Existing Buildings. London: RIBA Publishing, 2004.

Coleman, Peter. Shopping Environments: Evolution, Planning and Design. Oxford: Architectural Press, 2007.

Crawford, Margaret. "The world in a shopping mall.” In Variations on a Theme Park, edited by M. Sorkin, 3-30. New York: Noonday Press, 1992.

Dantzig, George B. and Thomas L. Saaty. Compact City: Plan for a Liveable Urban Environment. San Francisco: W. H. Freeman, 1973.

Dawson, John A. Shopping centre development. London: Longman, 1983.

Downton, Paul. Ecopolis, Architecture and cities for a changing climate. Dordrecht: Springer, 2009.

Ellin, Nan. "Integral Urbanism: A Context for Urban Design.” In Resilience in Ecology and Urban Design: Linking Theory and Practice for Sustainable Cities, edited by Steward Pickett, M.L. Cadenasso, and Brian McGrath, 63-78. New York: Springer, 2013.

Eppli, Mark J. and John D. Benjamin. "The Evolution of Shopping Center Research: A Review and Analysis." The Journal of Real Estate 9 (1) (1994): 5-32.

Goss, Jon. "Modernity and postmodernity in the retail built environment." In Ways of seeing the world, edited by F. Gayle and K. Anderson. London: Unwin Hyman, 1992.

Goss, Jon. "The "Magic of the Mall": An Analysis of Form, Function, and Meaning in the Contemporary Retail Built Environment." Annals of the Association of American Geographers 83, No. 1., Mar., (1993): 18-47.

Gurran, Nicole, and Elisabeth Namin. "Urban form and the climate change, Balancing adaptation and mitigation in the U.S. and Australia." Habitat International (2009): 33.

Handy, Susan. "Methodologies for Exploring the Link Between Urban Form and Travel Behavior." Series: Transportation Research, Transport and Environment, D 2 (2), (1996): 151-165.

Hankey, S., G. Lindsey, and J. D Marshall. "Population-level exposure to particulate air pollution during active travel: planning for low-exposure, health-promoting cities." Environ Health Perspect. Vol. 4 (2016): 527-34.

Howard, Gillette Jr. "The Evolution of the Planned Shopping Center in Suburb and City.” Journal of the American Planning Association 51:4 (2007): 449-460.

Jabareen, Yosef R. "Sustainable Urban Forms - Their Typologies, Models, and Concepts." Journal of Planning Education and Research 26 (2006): 38-52.

Jacobs, Jane. The Death and Life of Great American Cities: The Failure of Town Planning. New York: Random House, 1961.

Jenks, Mike and Nicola Dempsey. Future Forms and Design for Sustainable Cities, Oxford: Architectural Press. 2005 . 
Jenks, Mike and Colin Jones. Dimensions of Sustainable City, Vol. 2. London: Springer, 2010.

Jenks, Mike, Elizabeth Burton, and Katie Williams. The Compact City: A Sustainable Urban Form?. London: E \& FN Spon, 1996.

Karrholm, Mattias. "Setting the Scale of Sustainable Urban Form - scale-related problems discussed in the context of a Swedish urban landscape." Conference Architectural Inquiries, Göteborg, 2008.

Kent, Tony. "Creative space: design and the retail environment." International Journal of Retail \& Distribution Management 35(9) (2007): 734-745.

Kirby, Audrie E. and Anthony M. Kent. "Architecture as brand: store design and brand identity." Journal of Product \& Brand Management 19 Issue 6 (2010): 432-439.

Kirby, Audrie E. and Kent, Anthony M. "The local icon: re-use of buildings in place marketing." Journal of Town and City Management, 1(1), 2010: 80-91.

Maclaran, Pauline and Brown, Stephen. "The Center Cannot Hold: Consuming the Utopian Marketplace.” Journal of Consumer Research, 32(2), (2005) :311-323.

Martin, Leslie and Lionel March. Urban Space and Structures. UK: Cambridge University Press, 1972.

Melia, Steve, Graham Parkhurst and Hugh Barton. "The paradox of intensification." Transport Policy 18, Issue 1 (2011): 46-52.

Newman, Peter and Jeffrey Kenworthy. Cities and Automobile Dependence, An International Sourcebook. Gower: Aldershot, 1989.

Onay, Saglar N. "Commercial use of Antique interiors: dialectics of the contemporary and the conservative.” International Journal of Academic Research, 5(4) (2013): 161-168

Pickett, Steward. T. A., M. L. Cadenasso and Brian McGrath. Resilience in Ecology and Urban Design - Linking Theory and Practice for Sustainable Cities, London: Springer, 2013.

Plevoets, Bie and Koenraad Van Cleempoel. "Adaptive Reuse and Regeneration in Retail Design." In Retail-Design: Theoretical Perspectives, edited by Ann Petermans, Anthony Kent, 114-134. London: Routledge, 2016.

Ratti, Carlo, Dana Raydan, and Koen Steemers."Building form and environmental performance: archetypes, analysis and an arid climate." Energy and Buildings 35 (2003): 49-59.

Raven, Jeffrey. "Cooling the Public Realm: Climate-Resilient Urban Design.” In Resilient Cities: Cities and Adaptation to Climate Change, edited by Konrad Otto-Zimmermann, 451-463. Heidelberg: Springer, 2011.

Rio Fernandes, Jose A. "Sustainable urbanism: reducing, recycling, and reusing in a larger and more complex urban space." In Urban changes in different scales: systems and structures, edited by Lois González, Ruben Camilio, 251-264. Universidad de Santiago de Compostela, 2006.

Robertson, Kent A. "Downtown Retail Revitalization: A Review of American development strategies." Planning Perspectives no. 12 (4) (1997): 386-401.

Saaty, Thomas L. The Analytic Hierarchy Process: Planning, Priority Setting, Resource Allocation. Mc Graw Hill, New York, 1988.

Schindler, Mirjam and Geoffrey Caruso. "Urban Compactness and the Trade-off Between Air Pollution Emission and Exposure: lessons from a Spatially Explicit Theoretical Model." Computer Environ Urban 45 (2014): 13-23.

Song, J., A.Webb, B. Parmenter, D. Allen and E. Mcdonald-Buller. E. "The Impacts of Urbanization on Emissions and Air Quality: Comparison of Four Visions of Austin, Texas." Environ Sci, Technol. No. 19 (2008):294-300. 
Van Nes, Akkelies. "A configurative approach to understand pedestrian based and car-based shopping centres: Configurative studies on Oslo and Eindhoven". In Proceedings of The Fourth International Space Syntax Symposium. London 2003: 78.

Warnaby, Gery. "Towards a service-dominant place marketing logic.” Marketing Theory 9, No. 4 (2009): 403-423.

Yang, Perry Pei-Ju. "Energy Resilient Urban Form: A Design Perspective." The 7th International Conference on Applied Energy - ICAE2015. (2015) 


\section{FAKTOR PARTICIPACIJE U ODRŽIVOSTI NAKON TEHNOESTETIZMA I EKOLOŠKE MODERNIZACIJE \\ Goran Ivo Marinović}

Disperzivno tumačenje ekoloških tema u arhitekturi stvara osnov za konfuziju i kontradiktornosti svojstvene izazovima održivog. Odnos između održivosti i njenog prezentovanja u arhitekturi je problematičan. U savremenoj arhitektonskoj praksi termin održivosti je često nešto više od modernog izraza ili pogodne reči. Analiziranjem bezbrojnih projekata, članaka i knjiga na temu održivog projektovanja, očigledno je da je održiva arhitektura inkorporirala nepotrebno ograničenu i neadekvatnu konceptualizaciju ekologije društva. U cilju prevazilaženja ove deduktivne logike održive arhitekture, ovaj rad ima dva cilja. Prvo, istražuje različite ideje ekološke održivosti. Ovaj rad tvrdi da se u osnovi moraju revidirati fokus i obim rasprave o održivoj arhitekturi. Kao drugo, kroz rad Čileanskih arhitekata Elemental-a, ovaj rad razjašnjava pitanja procesa projektovanja u izgradnji stambenih jedinica poštujući praksu participacije članova zajednice i istražuje proces projektovanja stanovanja u kontekstu društveno-ekoloških aspekata. Kroz konkretisanje argumenta, ovaj rad istražuje najdominantnije interpretacije ekoloških i društvenih karakteristika $\mathrm{u}$ arhitektonskom procesu projektovanja stanovanja.

KLJUČNE REČI: FAKTOR PARTICIPACIJE U ODRŽIVOSTI, STAMBENA ARHITEKTURA, ELEMENTAL

\section{INTEGRISANI TRŽNI CENTAR KAO KOMPONENTA KOMPAKTNOG GRADA Marija Cvetković, Ivan Simić}

U ovom radu je prikazan koncept kompaktnog grada koji, za razliku od drugih koncepta održive urbane forme, gotovo u potpunosti uključuje sve relevantne teme održivog urbanog razvoja, kao što je povećanje gustine razvoja, kombinovanje funkcija, širenje grada, kao i postizanje socijalne i ekonomske raznolikosti i vitalnosti. Integrisane tržne centre ćemo posmatrati kao komponente kompaktnog grada i uspostavićemo njihov odnos sa konceptom kompaktnog grada i njegovim karakteristikama. Koncept tržnog centra u istorijskom gradskom jezgru nije izvorno održiv koncept. Umesto toga, urbana reciklaža starih industrijskih objekata koji se nalaze u blizini centra grada u funkciji maloprodaje se smatra održivijim konceptom i može se smatrati komponentom kompaktnog grada. Cilj ovog istraživanja je da se ispita značaj integrisanog pešačkog okruženja za urbani prostor u okviru koncepta kompaktnog grada. U cilju utvrđivanja stepena kompatibilnosti između principa održivog urbanog oblika i principa dizajna integrisanog tržnog centra, analiziraćemo nekoliko studija slučaja trgovačkih centara u Češkoj i Poljskoj.

KLJUČNE REČI: KOMPAKTNI GRAD, INTEGRISANI TRŽNI CENTAR, ODRŽIVA URBANA FORMA, URBANA RECIKLAŽA 